\title{
Effect of Growing Environment, Fruit Maturity and Sowing Time on Germination and Seedling Growth of Gmelina arborea Roxb.
}

\author{
Y.B. Patil ${ }^{1,3 *}$, H.S. Saralch ${ }^{1}$, S.R. Mahale $^{2}$, S.K. Chauhan ${ }^{1}$ and Rajni Sharma ${ }^{1}$ \\ ${ }^{1}$ Department of Forestry and Natural Resource, Punjab Agricultural University, \\ Ludhiana - 141 004, India \\ ${ }^{2}$ College of Forestry, Dapoli, Maharashtra, 415712, India \\ ${ }^{3}$ Maharashtra Nature Park Society, Sion-Bandra Link road, Dharavi, Mumbai-400 017, India \\ Corresponding author
}

\section{A B S T R A C T}

\section{Keywords}

Gmelina arborea,

Growing

environment, Fruit

maturity, Sowing

months,

Germination,

Seedling growth

\section{Article Info}

Accepted:

17 November 2018

Available Online:

10 December 2018
Seeds of Gmelina arborea many times do not germinate due to unknown reason. So the study was initiated to determine optimum stage of fruit maturity (green, yellow and yellow brown), suitable growing environment (agro-net shade and open field condition) and sowing time (August, September, October, November, December and January) on germination and seedling growth. Significant differences were exhibited among the fruit maturity levels, growing environment and sowing time for all the traits. Seed collected from yellow brown stage sown under agro-net shade during August month gave superior germination percentage (84.66\%), seedling height (24.02 $\mathrm{cm})$ and root length $(23.44 \mathrm{~cm})$, followed by September month. Green fruit harvesting stage had poor germination, germination energy and seedling growth under both the growing environments. Hence for good quality planting of Gmelina arborea seed should be collected from yellow brown stage and sown under agro-net shade during August month.

\section{Introduction}

Gmelina arborea Roxb. belongs to family verbenaceae, commonly known as gamar or white teak or yemane, is a rapidly growing with straight trunk and numerous spreading branches which form large shady crown. It is native to India, Bangladesh, Sri Lanka, Myanmar, Thiland, Southern China, Laos, Cambodia, Pakistan, Vietnam and Sumatra in Indonesia. G. arborea is very site specific, prefers moist fertile valleys, deep clay loams and also grows on dry sandy or poor soils (Tewari, 1995). In India, it is wide spread in whole of the country excepting in northern states (Fig. 1). It is a light demander, moderately frost hardy and has good power of recovering and doesn't withstand excessive drought and bad drainage. The wood of this species is considered as one of the best timber of tropics because of its multiple uses, useful for particle board, plywood, core stock, pit probs, matches and sawn timber for light construction, general carpentry and packaging 
(Duke, 1983). The wood is also used for pulp as well as for fuelwood and charcoal. In India and particularly in northeast region, it is grown extensively on government and private lands and has been substantially contributing in timber, fodder and industrial wood. Growth rates for Gmelina arborea have been reported to be as high as $40-50 \mathrm{~m}^{3} \mathrm{ha}^{-1}$ year $^{-1}$ in areas of good soils and rainfall in southern Costa Rica (Zeaser, 1998) but on average sites probably productivity is $15-21 \mathrm{~m}^{3} \mathrm{ha}^{-1}$ year $^{-1}$ for adapted landrace material throughout the tropics and subtropics. Because of its fastgrowing nature, straight stem, moderate shade effect on agriculture crops and huge market demand, this species was introduced and planted in agricultural landscapes as farm forestry/agroforestry species.

Seeds of Gmelina arborea many times do not germinate due to unknown reason. The inability of gamar seeds to germinate may be due to over ripeness or over fermentation of the pulpy part of the fruit causing death of the embryo (Omoyiola, 1974; Okoro, 1983; Hartman and Koster, 1975). In present day forestry, it is important to produce quality seedlings by inducing morpho-physiological changes in the plants for making them competent enough to bear the shock of field planting and enhance their productivity. Early growth and survival of seedlings are important aspects of forest management to ensure quick economic returns of the species (Chauhan and Sharma, 1997; Ginwal et al., 2004). Therefore, standardization of nursery techniques is the first step for raising successful plantations. Quality characters are influenced by many factors such as growing environment, fruit maturity, sowing months and other management aspects. This study was therefore, conducted to determine the effects of growing environment, fruit collection stage and sowing time on seed germination and seedling growth of Gmelina arborea.

\section{Materials and Methods}

The study was conducted in the experimental area of Department of Forestry and Natural Resources, Punjab Agricultural University, Ludhiana, during the months of AugustJanuary (2014-15). The study area is located at $247 \mathrm{~m}$ above sea level and lies at $30^{\circ} 45^{\prime} \mathrm{N}$ latitude and $75^{\circ} 40^{\prime} \mathrm{E}$ longitude. On an average site receives $704 \mathrm{~mm}$ rainfall, which is not evenly distributed in different seasons but most of it (75-80 \%) is received during July and September. The fruits were collected manually from the middle-aged, vigorous trees at green, yellow and yellow brown stage. For sowing of seeds for germination, fruits were depulped for seed extraction and were soaked in cold water at room temperature for 48 hours prior to sowing. The seeds were directly sown in polythene bags filled with Soil: FYM proportion of 2:1. After filling, the polythene bags were placed under open field condition and agro-net shade every data was recorded after 30 days of sowing. The meteorological data of the study area is given in Figure 2. The experiment was laid out in Split-split plot design with twenty seed per treatment in three replications consisted two growing environment viz. agro-net shade $\left(\mathrm{E}_{1}\right)$ and open field condition $\left(E_{2}\right)$ in main plots, three fruit collection stage viz. green $\left(F_{1}\right)$, yellow $\left(F_{2}\right)$ and yellow brown $\left(\mathrm{F}_{3}\right)$ in sub-plot and six sowing times viz. August $\left(\mathrm{M}_{1}\right)$, September $\left(\mathrm{M}_{2}\right)$, October $\left(\mathrm{M}_{3}\right)$, November $\left(\mathrm{M}_{4}\right)$, December $\left(\mathrm{M}_{5}\right)$ and January $\left(\mathrm{M}_{6}\right)$ in sub-sub plot. Seedlings were suitably managed by providing required management practices of irrigation weeding, etc. Data on different germination and growth parameters was uniformly recorded after 30 days.

\section{Statistical analysis}

The data were eventually analyzed using CPCS 1.0 software to estimate the extent of variation among the imposed treatments. 


\section{Results and Discussion}

\section{Effect of growing environments on seed germination and seedlings growth}

The results of seed germination and seedling growth as influenced by growing environment were statistically significant for germination and growth parameters. The seeds sown under agro-net shade showed higher germination percentage i.e. 38.20 per cent and germination energy i.e. 14.30 per cent than open-field condition i.e. 30.50 per cent, 12.35 per cent, respectively. The seedling parameters viz., seedling height $(9.59 \mathrm{~cm})$, collar diameter $(1.33 \mathrm{~mm})$, seedling tap root length $(11.20 \mathrm{~cm})$, total dry biomass $(0.79 \mathrm{~g})$ and root: shoot ratio $(0.22)$ were higher under agro-net shade conditions than that in openfield conditions, $5.91 \mathrm{~cm}, 0.94 \mathrm{~mm}, 7.90 \mathrm{~cm}$, $0.58 \mathrm{~g}$ and 0.19 , respectively.

Germinating seedlings do not depend on photosynthesis for a significant source of nutrition because they can live on the reserves stored in their seed. Thus, moisture is more important than light at the germination stage of development (Morris et al., 1999). Environments with high moisture availability, and low light levels established seedling successful than in open condition. Greater moisture would protect seeds from drying out excessively because seeds cannot tolerate drying. Lower moisture content and cooler temperature decline the seed viability (Harrington, 1972). So, the higher germination percentage, germination energy and seedling parameters were recorded in agro-net shade condition may be due to high moisture, optimum temperature and other micro-climatic conditions, which promoted germination and growth more effectively over open field conditions (Table 1).

The present findings are in agreement with the findings of Thompson and Schultz (1995),
Morris et al. (1999), Chaudhary (2001), Jacobs et al. (2005), Luna and Chamoli (2008); Tabin and Shrivastava (2014) in Quercus rubra, Swietenia macrophylla, Aquilaria malaccensis Albizia procera, Acacia catechu Eucalyptus tereticornis, respectively.

Effect of fruit collection stages on seed germination and seedlings growth

The results in table 2, depict the observation on different seed germination parameters and growth parameters as influenced by different fruit collection stages i.e. $F_{1}$ (Green), $F_{2}$ (Yellow) and $\mathrm{F}_{3}$ (Yellow brown). Gmelina arborea seed attained significantly higher germination $(45.94 \%)$ in yellow brown fruit collection stage followed by yellow (41.75\%) and less germination in green stage (15.36\%) displaying significant difference among themselves. As values for germination energy was 5.37 per cent, 15.34 per cent and 19.13 per cent and for that germination value recorded was $0.86,3.61$ and 4.67 in the green, yellow and yellow brown stages respectively.

It is clearly evident from the data that seedling growth parameters attained significantly superior values when seed collected at yellow brown stage. The seedlings height $(9.16 \mathrm{~cm})$, collar diameter $(1.30 \mathrm{~mm})$, tap root length $(10.82 \mathrm{~cm})$, total biomass $(0.85 \mathrm{~g})$ and root: shoot $(0.25)$ was observed higher in seedlings when seed from yellow brown fruit collection stage were sown followed by statistically different values of $8.30 \mathrm{~cm}, 1.19 \mathrm{~mm}, 9.77$ $\mathrm{cm}, 0.66 \mathrm{~g}$ and 0.21 respectively in yellow fruit stage, whereas, the minimum respective value for these parameters was recorded in green fruit collection stage i.e. $5.79 \mathrm{~cm}, 0.92$ $\mathrm{mm}, 8.06 \mathrm{~cm}, 0.16 \mathrm{~g}$ and 0.15 .

Minimum seed germination in green fruits may be due to the physiological immaturity. At this stage, nutrient may be still flowing in the seed from the parent trees. The seed might 
attain physiological maturity somewhere between yellow and yellow brown stage as indicated by maximum germination during this phase of seed maturity. It is well known that good germination is related to higher starch, soluble protein, total free amino acid and low phenol content. The level of these macro-molecules might be at their optimum level in physiologically mature seed at yellow brown stage, thereby giving better germination response (Kumar et al., 2007). The findings of this study were in agreement with Adebisi et al. (2011) and Saralch and Singh (2013) who reported that Gmelina arborea seed collected from yellow brown stage had maximum germination followed by yellow stage and less in green and brown stages.

\section{Effect of sowing time on seed germination and seedlings parameters}

In the present investigations, the seed sown during the month of August had recorded significantly higher values for seed germination and seedlings parameters, followed by September month sowing, whereas, seed sown from October to January recorded minimum values for all these parameters (Table 3).

The significantly maximum values for seedling height, collar diameter, tap root length, total biomass and root: shoot ratios were observed in August month i.e. $16.23 \mathrm{~cm}$ and $1.80 \mathrm{~mm} 13.85 \mathrm{~g}$ and 0.43 followed by $14.80 \mathrm{~cm}$ and $1.74 \mathrm{~mm}, 12.99 \mathrm{~g}$ and 0.29 in September month. Drastic fall was recorded from October to January in these parameters.

Optimum temperature for germination varies with species because at optima, seed is biochemically very active and minor fluctuations above and below, checks the rate of biochemical activity, which shows results in inhibition or slowing down of germination as well as growth of plants (Robert, 1967 and Thompson, 1970). Gupta and Pattanath (1976) reported that the germination of gamar is mainly depended upon conditions in the germination bed. Assuming optimal conditions, both temperature and light seem to affect germination. The early sowing date continued to enjoy greater soil moisture and favorable growing conditions, which can help the seedlings to have greater survival (McCreary, 1990). Earlier germination provides early establishment and growth before beginning of dry season.

As it is evident from the documented data (Fig. 2) that temperature of the present study site was optimum for germination of the seeds sown in the month of August and September, after that there was fluctuation in temperature from October month and minimum temperature recorded in November, December and January which was not optimum for germination of Gmelina arborea seeds, so there was less germination recorded during these months. Khan et al. (2007) also reported that when seeds of Cedrus deodara and Pinus halepensis sown in first fortnight of February had higher plant and collar diameter due to favorable growing environment instead of sowing seeds in the autumn season.

\section{Effect of growing environments (E) and} fruit collection stages (F) on seed germination and seedlings parameters

The growing environment and fruit collection stage interactions $(\mathrm{E} \times \mathrm{F})$ were found to exert significant influences on seed germination and seedlings parameters in Gmelina arborea. Seed sown in agro-net shade condition and collected from yellow brown stage (E) recorded statistically higher values for seed germination $(52.22 \%)$, germination energy $(20.83 \%)$, seedling height $(11.56 \mathrm{~cm})$, collar diameter $(1.52 \mathrm{~mm})$, tap root length (12.85 $\mathrm{cm})$, total biomass $(0.39 \mathrm{~g})$ and root: shoot ratio $(0.28)$ than other treatment combinations as shown in figure 3 . 
Table.1 Effect of growing environments on seed germination and seedling growth

\begin{tabular}{|l|l|l|l|l|l|l|l|}
\hline Environment & $\begin{array}{l}\text { Germination } \\
(\%)\end{array}$ & $\begin{array}{l}\text { Germination } \\
\text { energy }(\%)\end{array}$ & $\begin{array}{l}\text { Seedling } \\
\text { height } \\
(\mathrm{cm})\end{array}$ & $\begin{array}{l}\text { Collar } \\
\text { diameter } \\
(\mathrm{mm})\end{array}$ & $\begin{array}{l}\text { Tap root } \\
\text { length } \\
(\mathrm{cm})\end{array}$ & $\begin{array}{l}\text { Total dry } \\
\text { biomass } \\
(\mathrm{g})\end{array}$ & $\begin{array}{l}\text { Root: } \\
\text { shoot } \\
\text { ratio }\end{array}$ \\
\hline $\begin{array}{l}\text { Agro-net } \\
\text { shade }\end{array}$ & 38.20 & 14.20 & 9.59 & 1.33 & 11.20 & 0.79 & 0.22 \\
\hline $\begin{array}{l}\text { Open field } \\
\text { conditions }\end{array}$ & 30.50 & 12.35 & 5.91 & 0.94 & 7.90 & 0.58 & 0.19 \\
\hline $\mathrm{CD}(\mathrm{p}=0.05)$ & 2.14 & 0.14 & 0.04 & 0.01 & 0.35 & 0.01 & 0.01 \\
\hline
\end{tabular}

Table.2 Effect of fruit collection stages on seed germination and seedling growth

\begin{tabular}{|l|l|l|l|l|l|l|l|}
\hline $\begin{array}{l}\text { Fruit } \\
\text { Maturity }\end{array}$ & $\begin{array}{l}\text { Germination } \\
(\%)\end{array}$ & $\begin{array}{l}\text { Germination } \\
\text { energy }(\%)\end{array}$ & $\begin{array}{l}\text { Seedling } \\
\text { height } \\
(\mathrm{cm})\end{array}$ & $\begin{array}{l}\text { Collar } \\
\text { diameter } \\
(\mathrm{mm})\end{array}$ & $\begin{array}{l}\text { Tap } \\
\text { root } \\
\text { length } \\
(\mathrm{cm})\end{array}$ & $\begin{array}{l}\text { Total } \\
\text { dry } \\
\text { biomass } \\
(\mathrm{g})\end{array}$ & $\begin{array}{l}\text { Root: } \\
\text { shoot } \\
\text { ratio }\end{array}$ \\
\hline Green & 15.36 & 5.37 & 5.79 & 0.92 & 8.06 & 0.16 & 0.15 \\
\hline Yellow & 41.75 & 15.34 & 8.30 & 1.19 & 9.77 & 0.66 & 0.21 \\
\hline $\begin{array}{l}\text { Yellow } \\
\text { brown }\end{array}$ & 45.94 & 19.13 & 9.16 & 1.30 & 10.82 & 0.85 & 0.25 \\
\hline $\begin{array}{l}\text { CD } \\
(\mathrm{p}=0.05)\end{array}$ & 1.65 & 0.01 & 0.1 & 0.02 & 0.19 & 0.005 & 0.01 \\
\hline
\end{tabular}

Table.3 Effect of sowing month on seed germination and seedling parameters

\begin{tabular}{|l|l|l|l|l|l|l|}
\hline Sowing Months & $\begin{array}{l}\text { Germination } \\
(\%)\end{array}$ & $\begin{array}{l}\text { Germination } \\
\text { energy }(\%)\end{array}$ & $\begin{array}{l}\text { Seedling } \\
\text { height } \\
(\mathrm{cm})\end{array}$ & $\begin{array}{l}\text { Collar } \\
\text { diameter } \\
(\mathrm{mm})\end{array}$ & $\begin{array}{l}\text { Tap } \\
\text { root } \\
\text { length } \\
(\mathrm{cm})\end{array}$ & $\begin{array}{l}\text { Root: } \\
\text { shoot } \\
\text { ratio }\end{array}$ \\
\hline August & 66.33 & 28.53 & 16.23 & 1.80 & 13.85 & 0.43 \\
\hline September & 60.22 & 23.26 & 14.80 & 1.74 & 12.99 & 0.25 \\
\hline October & 40.50 & 18.27 & 7.13 & 1.19 & 9.83 & 0.20 \\
\hline November & 18.00 & 5.21 & 3.61 & 0.78 & 7.42 & 0.13 \\
\hline December & 13.00 & 2.21 & 2.36 & 0.69 & 6.75 & 0.12 \\
\hline January & 8.05 & 2.21 & 2.31 & 0.62 & 6.45 & 0.09 \\
\hline CD $(\mathrm{p}=0.05)$ & 2.03 & 0.12 & 0.11 & 0.02 & 0.16 & 0.01 \\
\hline
\end{tabular}


Figure.1 Map for geographical distribution of Gmelina arborea

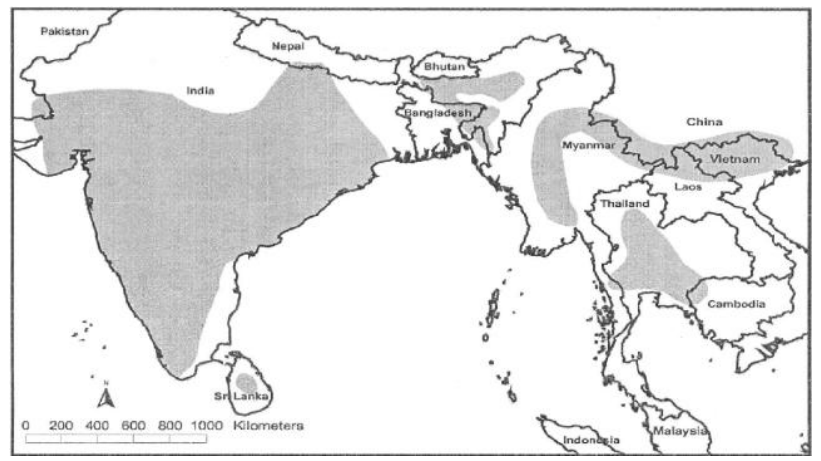

Figure.2 Meteorological parameters of the study site for the period April (2014) - February (2015)

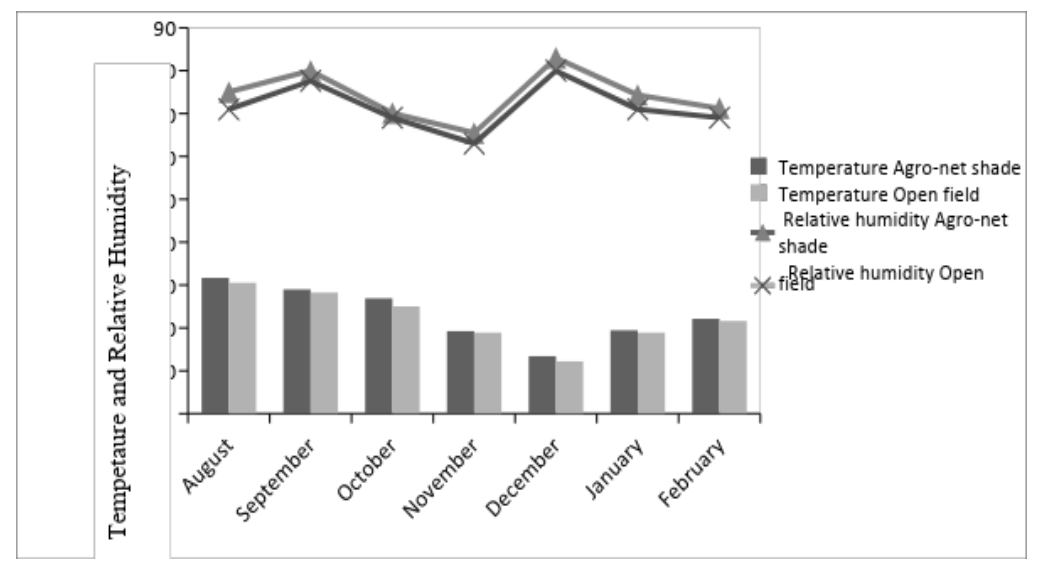

Figure.3 Effect of growing environment $(\mathrm{E})$ and fruit collection stage $(\mathrm{F})$ on germination and seedlings parameter

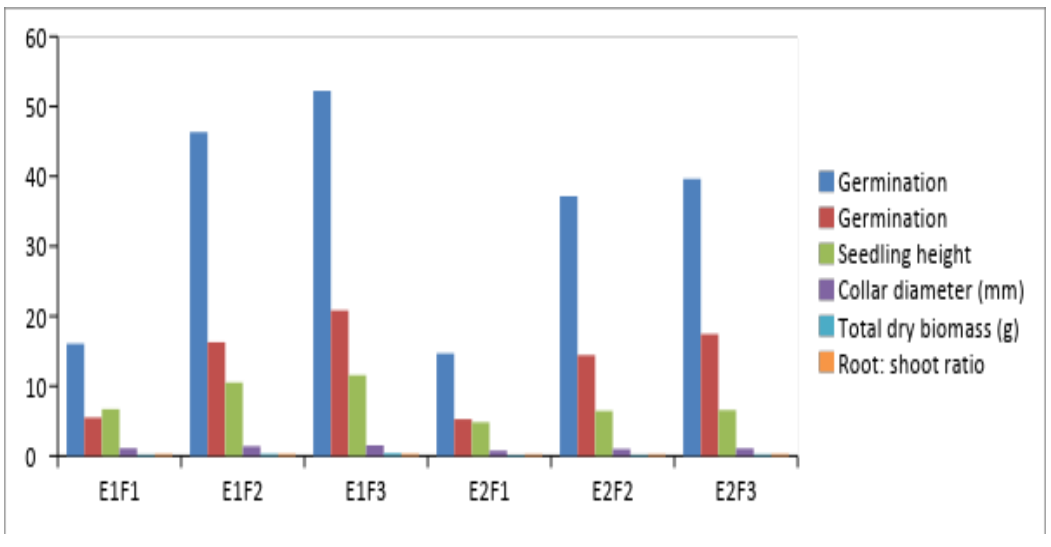


Figure.4 Effect growing environments (E) and sowing months (M) on seed germination and seedling parameters

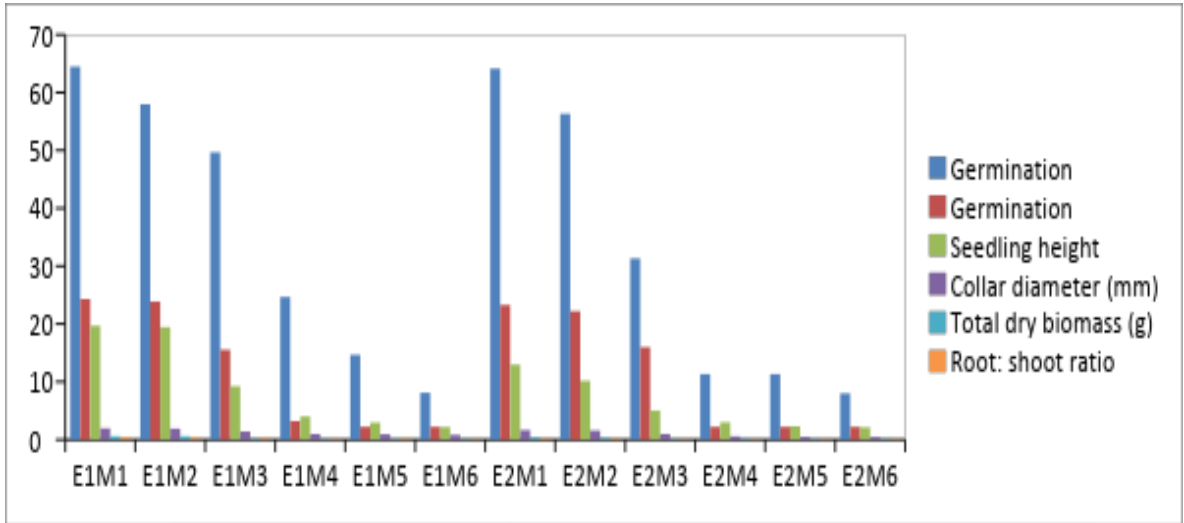

Figure.5 Effect growing environments (E) and sowing months (M) on seed germination and seedling parameters

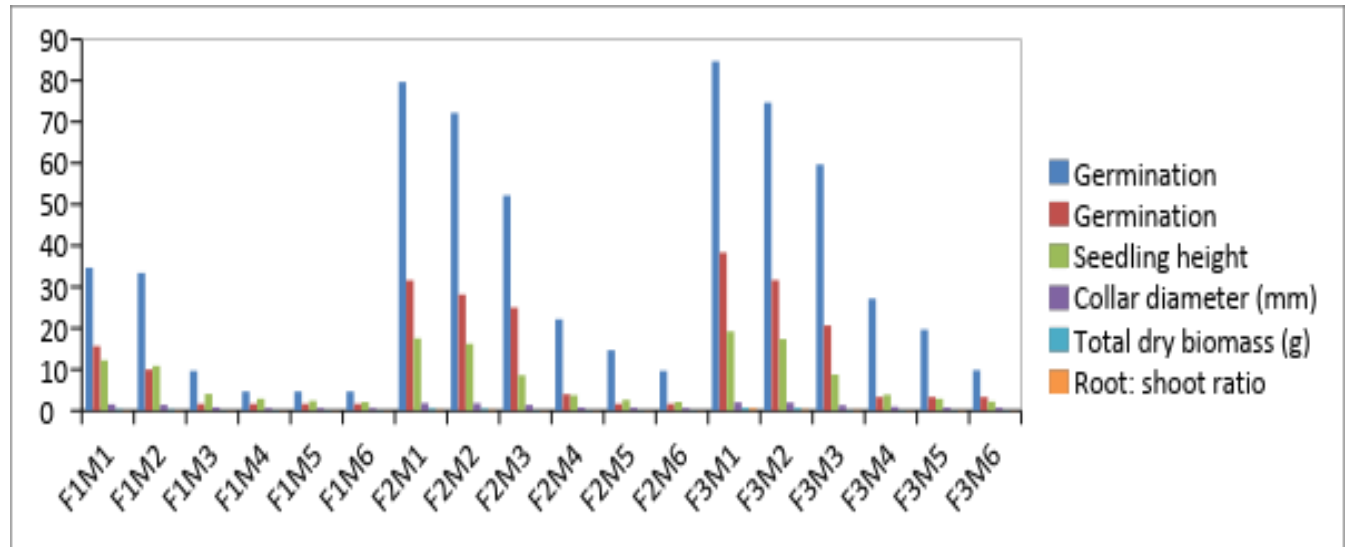

Figure.6 Effect of three-way interaction (growing environment $\times$ fruit maturity $\times$ sowing month) on Germination percentage

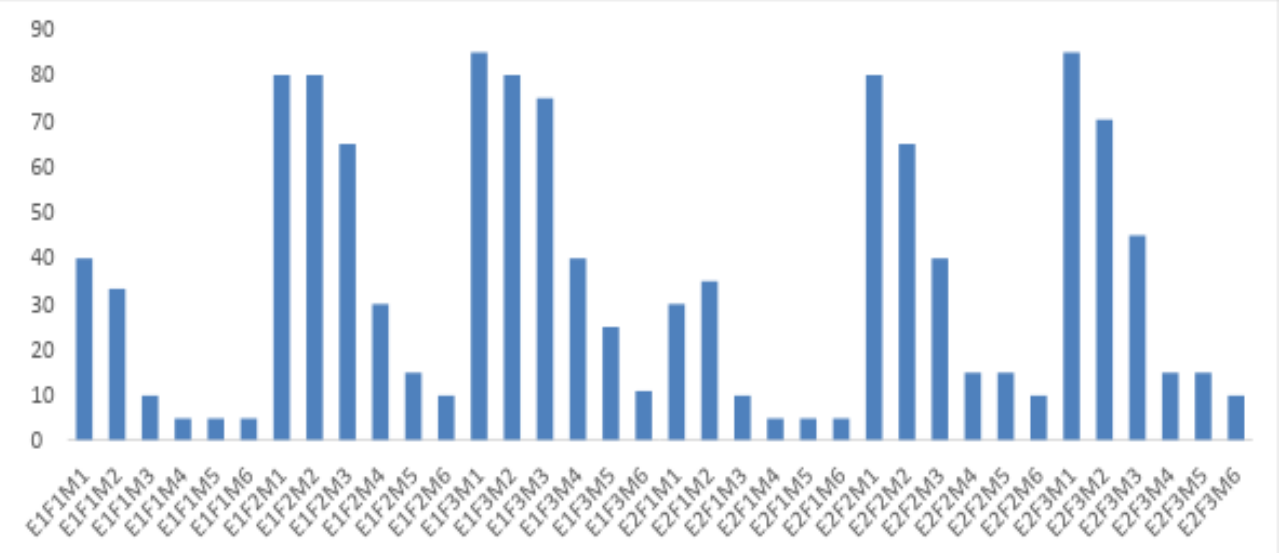


Figure.7 Effect of three-way interaction (growing environment $\times$ fruit maturity $\times$ sowing month) on seedlings parameter

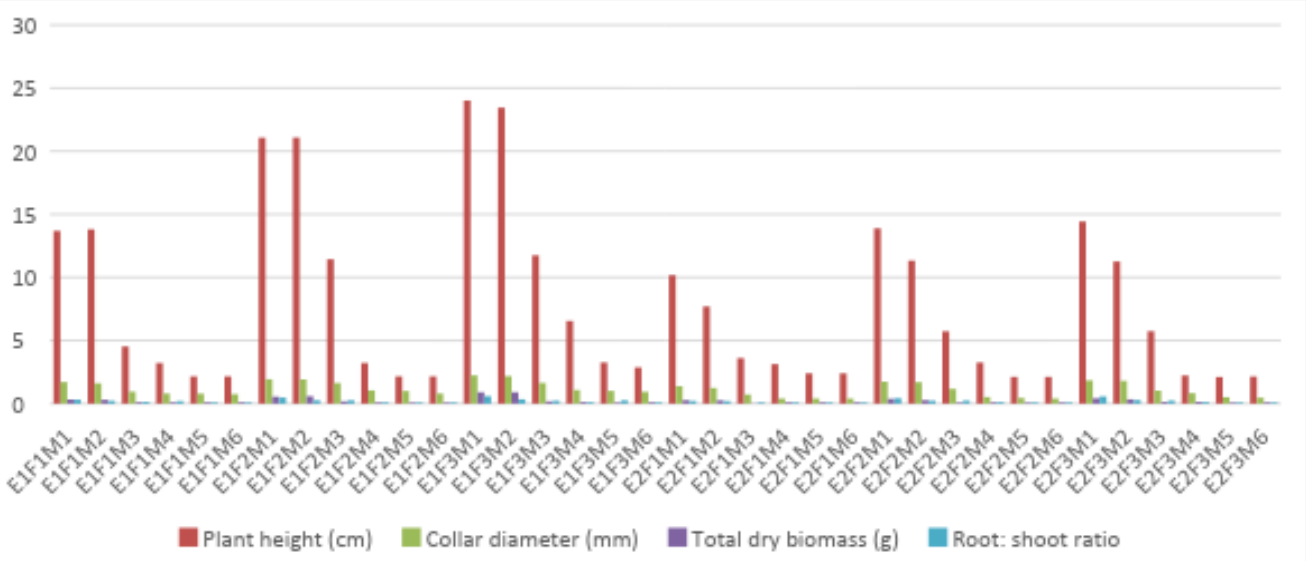

Effect growing environments (E) and sowing months (M) on seed germination and seedlings parameters

Seed sown under agro-net shade-conditions during August month were best for seed germination, seedlings parameter than the seeds sown under open field conditions during different months (Fig. 4).

Among agro-net shade and seed sown during August month recorded statistically higher values for germination $(64.47 \%)$, germination energy (24.32 \%), seedling height $(19.69 \mathrm{~cm})$, collar diameter $(1.96 \mathrm{~mm})$, tap root length $(17.92 \mathrm{~cm})$, total biomass $(0.60 \mathrm{~g})$ and root: shoot ratio (0.39). There were fall in all germination and seedling characters recorded from October to January and within these months, minimum value was recorded in January month.

Effect of fruit collection stages (F) and sowing months $(M)$ on seed germination and seedlings parameters

Seed collected from yellow brown stage sown during August month were recorded maximum values for seed germination (84.67 $\%$ ) and seedling parameters than collected from yellow and green stage. The green stage sown seed has recorded minimum values as compared to other seed collection stage for all the parameters. There were fall in all germination and seedling characters recorded from October to January and within these months, minimum value was recorded in January month (Fig. 5).

\section{Three-way interaction (Growing environment $\times$ Fruit maturity $\times$ Sowing month)}

The three-way interaction $(\mathrm{E} \times \mathrm{F} \times \mathrm{M})$ revealed significant differences in different combinations of treatments for all the germination and seedling growth parameters. The treatment combination of seed collected from yellow brown stage sown during August month under agro-net shade i.e. $\mathrm{E}_{1} \mathrm{~F}_{3} \mathrm{M}_{1}$ recorded maximum germination $(84.66 \%)$ and all the seedling parameters such as seedling height $(24.02 \mathrm{~cm})$, collar diameter $(2.23 \mathrm{~mm})$ tap root length $(23.44 \mathrm{~cm})$, total dry biomass $(0.90 \mathrm{~g})$ and root: shoot ratio (0.59) were recorded highest for this treatment as compared to other treatment combination, whereas, seed sown under open field condition during August month and collected from yellow brown stage i.e. $\mathrm{E}_{2} \mathrm{~F}_{3} \mathrm{M}_{1}$ was also 
equally good (86.44\%) but seedling growth values were much lower seedling height $(14.43 \mathrm{~cm})$, collar diameter $(1 . .84 \mathrm{~mm})$ tap root length $(11.77 \mathrm{~cm})$, total dry biomass $(0.42 \mathrm{~g})$ and root: shoot ratio (0.57) respectively (Fig. 6 and 7).

\section{References}

Adebisi, M.A., Adekunle, M.F. and Odebiyi, O.A. 2011. Effects of fruit maturity and pre-sowing water treatment on germinative performance of Gmelina aborea seeds. Journal of Tropical Forest Science 23(4): 371-378.

Bahar, N. 2010. Effect of fruit maturation on germination and vigour of the seed of Diploknema butyracea. Indian Forester 136: 1271-1273.

Bhardwaj, S.D. and Chakraborty, A.K. 1994. Studies on time of seed collection, sowing and presowing seed treatments of Terminalia bellirica Roxb. And Terminalia chebula Retz. Indian Forester 120: 430-439.

Chaudhary, A.K. 2001. Effect of shade on growth performance of four tree species in nursery stage. Pakistan Journal of Agriculture Science 38(1-2): 69-72.

Chauhan, S.K. and Sharma, R. 1997. Seedling quality evaluation: importance in afforestation. Advances in Forestry Research in India (Ed. Ram Prakash), IBD Dehradun. 17: 59-72.

Dvorak, W.S. 2004. World view of Gmelina arborea: opportunities and challenges. New Forest 28: 111-26.

Duke, J. 1983. Handbook of Energy Crops. Pp.25-60. Purdue University, Center for New Crops and Plant Products.

F.A.O.2002. http://www.fao.org/forestry/fo/country/ nav_world.jsp?lang_id $1 / 43$. Country Profiles.

Gerhardt, K. 1996. Effects of root competition and canopy openness on survival and growth of tree seedlings in a tropical seasonal dry forest. For Ecol Manage 82: 33-48.

Ginwal, H.S., Rawat, P.S., Bhandari, A.S. and Mandal, A. 2004. Potting mixture affects the seedling quality in Albizia procera (Robx.) Benth under root trainer seedling production system. Annals of Forestry 12: 172-181.

Gupta, B.N. and Pattanath, P.G. 1976. Germination response of some forest tree seeds under controlled conditions. Indian Forester 102(5): 264-272.

Hartma, H.J. and Koster, D.E. 1975. Plant Propagations. Third edition. Public Prentices Hall

Inc, Enlewood Cliffs

Harrington, J. 1972. Seed storage and longevity. In: Kozlowski, T.T. (Ed.), Seed Biology, vol III. Academic Press, New York. Pp. 145-245.

Jacobs, D.F, Salifu, K.F and Seifert, J.R. 2005. Relative contribution of initial root and shoot morphology in predicting field performace of harwood cuttings. New Forest 30: 235-251.

Khan, M.A, Mughal, A.H. and Mughloo, J. 2007. Effect of sowing dates on the germination and seedling growth of Cedrus deodara and Pinus halepensis. Indian Forester 133(7): 909-914.

Kulkarni, Y.A, Panjabi, R., Patel, V., Tawade, A. and Gokhale, A. 2012. Effect of Gmelina arborea Roxb in experimentally induced inflammation and nociception. Journal Ayurveda Integr Med 4: 152-157.

Kumar, A. 2007. Growth performance and variability in different clones of Gmelina arborea (Roxb.). Silvae Genetica 56(1): 32-36.

Kumar, D., Mishra, D.K. and Singh, B. 2007. Effect of temperature, media and light on germination of neem (Azadirachta indica A. Juss.) seed. Indian Forester 134: 1636-1642. 
Luna, R.K. and Chamoli, N. 2008. Evaluation of quality seedlings raised under agronet shade and direct sunlight. Indian Forester 134(1): 17-25.

Luna, T., Wilkinson, K. and Dumroese, R.K. 2009. Seed germination and sowing options. Pp. 133-51 in Dumroese RK, Luna $\mathrm{T} \&$ Landis TD (eds) Nursery manual for native plants: A guide for tribal nurseries. Washington, D.C.: U.S. Department of Agriculture, Forest Service.

Mccreary, D.D. 1990. Acorn sowing date affects field performance of blue and valley Oaks. CA. Tree Planters Notes 41(2): 6-9.

Morris, M.H., Negreros, C.P. and Mize, C. 1999. Sowing date, shade, and irrigation affect big-leaf mahogany (Swietenia macrophylla King). School of Natural Resources and the Environment, University of Michigan, Ann Arbor, MI 48109, USA.

Okoro, O.O. 1983. Revolutionizing procedure guarding G. arborea seed in Nigeria. Pp $1-12$ in

Proceedings of the 13th Annual Conference Forestry Association of Nigeria. Benin.

Omoyiola, B. 1974. Variation in early traits and productivity of $G$. arborea Roxb. Under

controlled environment conditions. $\mathrm{PhD}$ thesis, University of Aberdeen. Aberdeen.

Robert, K.V. 1967. Ranges of temperature tolerance for germination of Mimulus seeds from diverse population. Ecology
48(4): 647-651.

Saralch, H.S. and Singh, S. 2013. Determining maturity indices for time of seed collection in Gmelina arborea under Punjab conditions. Int J Farm Sci 3(2): 90-94.

Shaw, R. H. and Loomis, W. E. (1950) Basis for the prediction of corn yields. Plant Physiology 25: 225-244.

Tabin, T. and Shrivastava, K. 2014. Factors affecting seed germination and establishment of critically endangered Aquilaria malaccensis (Thymelaeaceae). Asian Journal of Plant Science and Research 4(6): 41-46.

Tewari, D.N. 1995. Monograph on Gmelina arborea. $\mathrm{Pp}$ 23. International Book Distributors, D. Dun.

Thompson, P.A. 1970. Characterization of the germination response to temperature and ecology. Nature 225: 827-831.

Thompson, J.R. and Schultz, R.C. 1995. Root system morphology of Quercus rubra L. planting stock and 3-year field performance in Iowa. New Forest 9: 225-236.

Umarani, R. and Vanangamudi, K. 2004. An introduction to seed technology. Pp. 2231. International Book Distributor, New Delhi.

Zeaser, D. 1998. Vegetative propagation of melina (Gmelina arborea Roxb.). In: CAMCORE. International Tree Breeding Short Course Book. North Carolina State University, Raleigh, North Carolina, USA. Pp. 27-34.

\section{How to cite this article:}

Patil, Y.B., H.S. Saralch, S.R. Mahale, S.K. Chauhan and Rajni Sharma. 2018. Effect of Growing Environment, Fruit Maturity and Sowing Time on Germination and Seedling Growth of Gmelina arborea Roxb.. Int.J.Curr.Microbiol.App.Sci. 7(12): 2543-2552. doi: https://doi.org/10.20546/ijcmas.2018.712.289 